Supporting Information

\title{
Synthesis of Oligo(ethylenediamino)- $\beta$-Cyclodextrins Modified Gold Nanoparticle as a DNA Concentrator
}

\author{
Hao Wang, Yong Chen, Xiao-Yun Li, Yu Liu*
}

Department of Chemistry, State Key Laboratory of Elemento-Organic Chemistry, Nankai University, Tianjin 300071, P. R. China

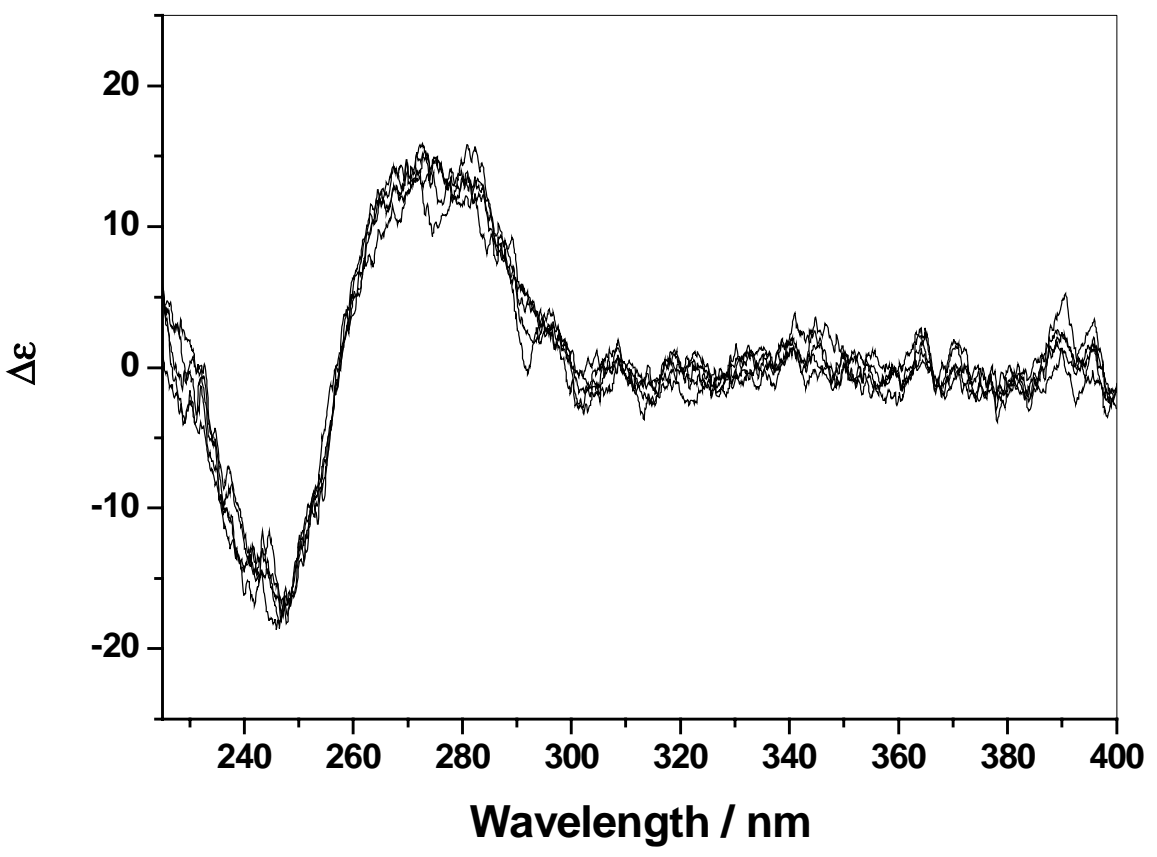

Figure S1 The circular dichroism spectral changes of ct-DNA $\left(0.15 \mathrm{mg} \mathrm{ml}^{-1}\right)$ upon addition of OEA-L-NP in $\mathrm{pH} 7.2$ phosphate buffer $(\mathrm{M}=0.1)$, the concentration of OEA-L-NP was $0,0.2,0.5,0.8$, 3.0, 6.0. cell length: $1 \mathrm{~cm}$. 